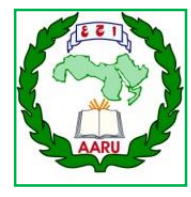

Arab Univ. J. Agric. Sci., Ain Shams Univ., Cairo, Egypt

28(4), 1131-1141, 2020

Website: http://ajs.journals.ekb.eg

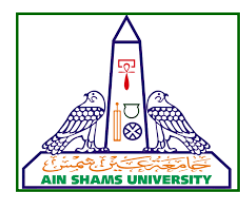

1131

\title{
Effect of Grape Pomace on Some Biological Assays of Experimental Rats
}

\author{
Maha A Mahmoud, Hala A Thabet*, El-Shahat G El-Dreny \\ Special Food and Nutrition Dept, Food Technol Res Inst, Agric Res Center, Giza, Egypt \\ *Corresponding author: drhala.thabet@gmail.com
}

Received 9 July, 2020

Accepted 2 October, 2020

\section{Abstract}

This study is carried out to reduce the environmental impact of grape proceeding wastes through study the effect of the grape pomace (GP) utilization on some biological parameters which reflect the health status of rats fed on high fat diets. It was carried out via an experimental biological study, where adult healthy male albino rats, weighing $185 \pm 5 \mathrm{~g}$, were fed on high-fat diets supplemented with 5,10 , and $15 \%$ of GP. The proceeding results showed that the protein amount in GP was up to $8.75 \%$, lipids content was $7.38 \%$ and the total dietary fiber was $46.63 \%$. K, Mg, Ca, Na, P and S were found in higher concentrations. The lipids of GP contained $85.75 \%$ unsaturated fatty acids $(19.14 \%$ monounsaturated and $66.60 \%$ polyunsaturated fatty acid).The predominant fatty acid was linoleic acid (65.29\%). Total phenolic (TP) compounds (expressed as mg gallic acid equivalent (GAE) per $\mathrm{g}$ sample) were about $50.35 \mathrm{mg} \mathrm{GAE} / \mathrm{g}$, total flavonoids (expressed as $\mathrm{mg}$ rutin equivalent (RE) per $\mathrm{g}$ sample) were $22.25 \mathrm{mg} \mathrm{RE} / \mathrm{g}$ and the DPPH radical scavenging activity was $51.92 \%$. Gallic acid was the most abundant polyphenols, $(9.76 \mathrm{mg} / 100 \mathrm{~g})$. Catechin was the most abundant flavonoid compound (52.5 mg/100g). Resveratrol as stilbenes content was $14.11 \mathrm{mg} / 100 \mathrm{~g}$. Supplementation of the highfat diet with GP resulted in a significant reduction in cholesterol, triglycerides, LDL-C and vLDL-C levels of the tested rat groups. Treated rats had higher mean values of HDL-C than that fed on HFD only. The best result for estimation of specific studied parameters (AST, ALT, urea, uric acid and creatinine) revealed that the rat groups fed on the high fat diet containing $15 \%$ GP was the healthiest. It was found that a non-significant alteration in the levels of AST, ALT, uric acid and creatinine, compared with the
\end{abstract}

negative control rat group was detected. Consequently, it could be concluded that GP could be considered as a source of healthy compounds that could be applied in animal feed, pharmaceutical, cosmetic or food industries.

Keywords: Grape pomace (GP), Total phenolic, Total flavonoids, Resveratrol, Biological assay

\section{Introduction}

Grapes are considered as the most value traditional fruit crops with a great global production. After processing, approximately 2.5 million tons of grape by-products are produced (Food and Agriculture Organization of the United Nations, 2012). Grape pomace (GP) is the main residue of grape processing, composed of skins, seeds and stems. It comprises approximately $25 \%$ of harvested grape weight during grape processing. After the manufacture of grape juice and wine, grape pomace represents a high waste problem. Such wastes could offer fundamental economic benefits if found value added tools (Fontana et al 2013).

In Egypt, grapes are considered the second main crop production after citrus, almost 200,000 Ton fruits, in which the by-product pomace represents about 10 to 20 thousand Tons/year (Ministry of Agriculture Egypt, Agricultural Development System Project, ADS. 2006).

In recent years, the possibility of conversion byproduct wastes to nutraceutical and value added products have an increased attention for their potential health benefits. These several biological properties are believed to be due to the presence of many healthy components. Dietary fibers are presence in grapes by-product with high concentrations having beneficial physiological effects; including 
gastrointestinal function improvement. Dietary fibers, also, caused a reduction in total cholesterol, low density lipoprotein (LDL-C) and moderation of postprandial insulin response (Llobera and Cañellas 2007).

The grape seed pomace oils rich in oleic and linoleic acids. Alpha-tocopherol was the most abundant tocopherol in the oil (Mildner-Szkudlarz and Bajerska 2013).

Phenolic compounds represent one of the most numerous, important and widely distributed groups of natural products in plant kingdom. Grape pomace is wealthy in secondary metabolites as phenolic components (Manach et al 2005).The majority of phenolic compounds in grape waste are flavonoids and phenolic acids which have been reported to have beneficial effects on the lipid metabolism (Lee et al 2009). Flavonoid intake has been inversely impact in relation to the coronary heart disease. Resveratrol is a major polyphenol compound in grape that is thought to be a potential contributor of several beneficial properties such as decreasing insulin resistance, preventing the heart failure and hypertension (Hertog 1993).

In addition, Lee et al (2009) reported that supplementation with grape skins was more effective in protecting against oxidative damage, through improving the antioxidant defense system in both rats fed a high-fat diet or fed a low-fat diet.

As is well known, environmental factors (e.g., soil, geographical location, and climate) and agronomic practices play key roles in grape pomace composition and associated properties. So, the current research concerned with studying of the effect of by product Egyptian grape pomace on health status parameters of rats fed on high fat diets. In addition, to investigate its antioxidant activity to assess its capacity as a source of natural antioxidants, thereby reducing the environmental effect of grapeproducing waste.

\section{Materials and Methods}

\subsection{Materials}

The grape pomace (GP), in this study was collected from El-Kroom Company, Alexandria Governorate, Egypt, which consist of skins, seeds and stems. Fresh GP was spread into thin layers in plastic trays and dried at $\left(20-22^{\circ} \mathrm{C}\right)$ in a well-ventilated room. Then, it was grounded into powder that was passed through the 40mesh sieve and was kept at $-18^{\circ} \mathrm{C}$ in a deep freezer until used.
All solvents, standards and chemicals were manufactured by Sigma-Aldrich Chemicals Co., USA and were purchased from Cornell lab company, Egypt. Analytical kits were manufactured by Randox Laboratories Ltd., Diamond Road, Crumlin, Co., Antrim BT29 4QY, United Kingdom and obtained from Biodiagnostic company, Egypt.

\subsection{Methods}

\subsubsection{Determination of proximate chemical com-} positions of GP

Moisture, protein, total fats, crude fibers, ash, soluble dietary fiber and insoluble dietary fiber contents of GP were determined according to AOAC (2006). Total dietary fiber was obtained by adding soluble dietary fiber and insoluble dietary fiber. Available carbohydrates based on dry weight were calculated by the differences as: $100-$ (ash +protein + total fats + crude fibers) in $100 \mathrm{~g}$ of GP.

\subsubsection{Determination of minerals contents in GP}

Mineral contents were determined by using Flame Atomic Absorption Spectrophotometer instrument, AAS (Model 3300, Perkin-Elmer, Beacons field, UK) by wet digestion as the procedure of the AOAC (2006) method.

\subsubsection{Determination of fatty acids in GP}

Fatty acid methyl esters were prepared from total lipid and injected into Gas chromatography system (GC), Agilent $6790 \mathrm{~N}$ series according to ISO12966-2 (2011) which was described in International Organization for Standardization (ISO).

\subsubsection{Determination of total phenolic com- pounds (TP), total flavonoids (TF) compounds and radical scavenging activity (RSA) in GP}

The same procedure of sample extraction as described by Yilmaz and Toledo (2006) was used to determine TP, TF and RSA. The total phenolic contents of GP were determined using the Folin-Ciocalteu method as described by Arnous et al (2001). The total flavonoids were determined by using Joyeux et al (1995) method.

The antioxidant activity of GP was estimated by determining the radical scavenging activity (RSA\%) of GP extract by the 1,1-diphenyl-2-picryl-hydrazyl (DPPH) assay as described by Brand-Williams et al (1995). The radical scavenging activity was calculated using the formula: 


$$
\left.\% \text { Inhibition }=\left[\left(A_{b}-A_{s}\right) / A_{b}\right)\right] \times 100 .
$$

Where: $A_{b}$ is absorbance of blank, $A_{s}$ is the absorbance of the GP extract

\subsubsection{Identification of phenolic acids, flavonoids and stilbenes in GP}

A High Performance Liquid Chromatography (HPLC), Agilent, Germany 1200 system equipped with a variable wavelength detector was used to determine phenolic acids, flavonoids and resveratrol as stilbenes. Samples preparation and chromatographic conditions were similar to those described by Sagdic et al (2011).

\subsubsection{Biological assay}

Adult healthy male albino rats (30 rats), weighing $185 \pm 5 \mathrm{~g}$, were obtained and housed at the animal house of Faculty of Veterinary Medicine Kafar El Shiekh University. Rats were randomly divided into five groups of six rats each. Rats were fed on a basal diet (BD) which was prepared according to Reeves et al (1993). Animals were acclimatized to the laboratory conditions for one week before starting the experiment.

The tested rats were isolated into two primary groups. The first one (six rats) was benefited from (BD) and kept as a negative control group (NC). The second (24 rats) were fed on a high-fat diet (HFD) for two weeks according to Wang et al (2007). After that the last group was divided into four subgroups, each one consists of six rats. The first subgroup was fed on the high-fat diet only until the end of experiment and kept as a positive control group (PC), while the other three subgroups were fed on the high-fat diet supplemented with 5, 10, and $15 \%$ of GP and known as 5\% GP, $10 \%$ GP and $15 \%$ GP, respectively.

At the end of the experiment ( 60 days), the tested rats were overnight fasted and then were sacrificed under anesthesia. Rat's blood were drawn into tubes and centrifuged at $3000 \mathrm{~g}$ for 15 $\min$. at $4^{\circ} \mathrm{C}$ to obtain serum that were kept frozen at $-18^{\circ} \mathrm{C}$ until analysis.

Total cholesterol (TC), high-density lipoprotein cholesterol (HDL-C) and Triglyceride (TG) Serum contents were determined according to the methods of Allain et al (1974), Lopes-Virella et al (1977) and Fossati and Prencipe (1982), respectively. Very low density lipoprotein cholesterol (vLDL-C) and Low density lipoprotein cholesterol (LDL-C) were calculated using Friedewald equations (Friedewald et al 1972) as follows:

$\operatorname{vLDL}-\mathrm{C}(\mathrm{mg} / \mathrm{dl})=$ Triglycerides $/ 5$. LDL-C $(\mathrm{mg} / \mathrm{dl})=($ Total cholesterol $-\mathrm{HDL}-\mathrm{C})-\mathrm{vLDL}-$ C.

Serum creatinine, urea and uric acid were estimated according to Bonsens and Taussky (1984), Patton and Crouch (1977) and Fossati et al (1980), respectively. The activities of Serum Aspartate Aminotransferase (AST) and Alanine Aminotransferase (ALT) were determined using the methods of Bergmeyer and Harder (1986).

\subsubsection{Statistical Assessment}

Statistically, the results were analyzed using a one-way variance analysis (ANOVA). The Duncan test was used to assess variations between treatments. All $p$ values of $<0.05$ have been deemed significant (Bouveresse et al 2011)

\section{Results and Dissction}

\subsection{Chemical composition of GP}

The proximate chemical composition of the GP is shown in Table 1. Moisture content is $6.61 \%$. This ratio is in agreement with Tangolar et al (2009) who reported that moisture content in seeds of seven grape varieties is between 4.95 to $6.54 \%$. But Ziarati et al (2017) found that it is ranged from 3.40 to $3.87 \%$. The amount of protein is corresponded to $8.75 \%$ of sample analyzed. It was closely with Sousa et al (2014), meanwhile, Guemour et al (2010) who reported that it was $14 \%$.

With regard to the lipid content, its value was $7.38 \%$ and nearly with findings of Gülcü et al (2018) who mentioned that the oil content in wine by products (pomace) was $8.9 \%$.

With respect to the amount of total dietary fiber, its value was $46.63 \%$. Such result is agreed with Sousa et al (2014) who found that it is $46.17 \%$. While, Bampi et al (2010) found that total dietary fiber was by $31.66 \%$. GP fibers are associated with polyphenols with antioxidant activity. So, GP fibers are structurally different from those found in other cereals and other fruits. 
Table 1. Proximate chemical composition of GP

\begin{tabular}{|l|c|}
\hline Parameters & $(\%)$ \\
\hline Moisture & $6.61 \pm 0.03$ \\
\hline Ash $^{*}$ & $7.20 \pm 0.10$ \\
Protein $^{*}$ & $8.75 \pm 0.16$ \\
Total lipids $^{*}$ & $7.38 \pm 0.04$ \\
Crude fiber $^{*}$ & $24.07 \pm 0.21$ \\
Available carbohydrate $^{*}$ & $52.60 \pm 0.36$ \\
\hline Total dietary fiber $^{*}$ & 46.63 \\
Soluble dietary fiber & 4.37 \\
Insoluble dietary fiber & 42.26 \\
\hline
\end{tabular}

"On dry weight basis. Each value represents the mean \pm standard deviation

The study of Deng et al (2011) on five varieties of GP indicated that insoluble DF weighed more than $95.5 \%$ of total DF in all samples. In the present study the insoluble DF weighted more than $90 \%$ of total DF. Although data about the soluble and insoluble fiber contents of GP vary from study to other, there is no doubt that GP fiber is low in solubility.

\subsection{Determination of fatty acids in GP}

The analysis of the fatty acid composition of the GP oil is described in Table 2. Palmitic, oleic and linoleic acids were the abundant fatty acids in GP oil. The highest fatty acid content was linoleic acid $(65.29 \%)$, followed by oleic $(18.7 \%)$, palmitic $(9.24 \%)$ and stearic acids (4.6\%). These findings were agreed with Anđelković et al (2015) who found that the highest fatty acid in the grape pomace oil was linoleic (72.4\%). Gülcü et al (2018), also, mentioned that, in general, the highest fatty acid was linoleic acid, followed by oleic, palmitic, and stearic acids.

It could be noticed, in the present study, that the lipids of GP represented about $85.74 \%$ unsaturated fatty acids (19.14\% monounsaturated and $66.60 \%$ polyunsaturated fatty acids). On the other hand, Fernandes et al (2013), in a previous study, reported that the content of monounsaturated fatty acids reached to $21.29 \%$ in some varieties of grape seeds.

The beneficial properties of unsaturated fatty acids, particularly with respect to the cardiovascular system are known. Grape seed oil is rich in unsaturated fatty acids, such as oleic and linoleic acids. The poly-unsaturated fatty acids, such as linoleic and linolenic acids, are essential for the human metabolism because of the lack of enzymes responsible for synthesis of these fatty acids. For this reason, they could be used as foods and so its oil (Diab et al 2017).

Table 2. Relative abundance (\%) of fatty acids in grape pomace

\begin{tabular}{|c|c|c|c|}
\hline \multicolumn{2}{|c|}{ Fatty acid } & $\begin{array}{c}\text { Relative } \\
\text { abundance } \\
(\%)\end{array}$ & Type \\
\hline Palmitic acid & C16:0 & 9.24 & \\
Stearic acid & C18:0 & 4.60 & \\
Arachidic acid & C20:0 & 0.25 & Saturated fatty acid \\
Behenic acid & C22:0 & 0.17 & $14.26 \%$ \\
\hline $\begin{array}{c}\text { Palmitoleic } \\
\text { acid }\end{array}$ & C16:1 & 0.20 & \\
Oleic acid & C18:1 & 18.73 & fatty acid 19.14\% \\
Gadoleic acid & C20:1 & 0.21 & \\
\hline Linoleic acid & C18:2 & 65.29 & \\
Y Linolenic & C18:3 & 0.49 & Polyunsaturated \\
acid & n6 & & fatty acid $66.60 \%$ \\
a Linolenic & C18:3 & 0.82 & \\
acid & n3 & & \\
\hline \multicolumn{2}{|l}{} \\
\hline
\end{tabular}

\subsection{Content of mineral in GP}

According to the present results of the minerals content $(\mathrm{mg} / 100 \mathrm{~g})$ shown in Table $3 \mathrm{~K}, \mathrm{Mg}, \mathrm{Ca}, \mathrm{Na}$, $P$ and $S$, with descending order, were the major elements in GP. While, $\mathrm{Fe}, \mathrm{Zn}, \mathrm{Cu}$ and $\mathrm{Mn}$ were presented in small quantities. These results are in accordance with those of Ziarati et al (2017) who reported that $\mathrm{K}$ had the highest content in GP followed by $\mathrm{Ca}$.

While, Gülcü et al (2018) showed that Fe was the main element in grape juice pomace (10.6 $\mathrm{mg} / 100 \mathrm{~g})$ followed by $\mathrm{P}, \mathrm{Mn}$ and $\mathrm{Zn}(2.1,1.6$ and $1.2 \mathrm{mg} / 100 \mathrm{~g}$, respectively). The current results showed some small differences compared to literature. These differences can be probably due to the parts of grape, processing equipment contamination, soil structure and fertilizer in growing stage.

Cetin et al (2011) mentioned that $\mathrm{K}$ levels were higher than those of $\mathrm{Na}$ and led to a mineral balance that favors hypertension control. A diet rich in $\mathrm{K}$ lowers blood pressure and consequently the risk of morbidity and mortality due to cardiovascular diseases. In addition, $\mathrm{K}$ intake can decrease urinary $\mathrm{Ca}$ excretion and consequently reduce the risk of develop in osteoporosis. 
Table 3. Minerals content of GP

\begin{tabular}{|c|c|}
\hline Minerals & $\begin{array}{c}\text { Amount } \\
\left(\mathrm{mg} / 100 \mathrm{~g}^{\star}\right)\end{array}$ \\
\hline Potassium (K) & 3668.73 \\
\hline Magnesium (Mg) & 1243.58 \\
\hline Calcium (Ca) & 1053.14 \\
\hline Sodium (Na) & 323.29 \\
\hline Phosphorus (P) & 219.57 \\
\hline Sulfur (S) & 159.50 \\
\hline Iron $(\mathrm{Fe})$ & 10.63 \\
\hline Zinc (Zn) & 2.30 \\
\hline Copper (Cu) & 2.04 \\
\hline Manganese $(\mathrm{Mg})$ & 1.42 \\
\hline
\end{tabular}

* as basis

\subsection{Total phenolic compounds, total flavonoids and DPPH in GP}

As observed in Table 4 the content of total phenolic compounds in GP, which expressed as mg gallic acid equivalent (GAE) per gram weight of sample, was $50.35 \mathrm{mg} \mathrm{GAE} / \mathrm{g}$. This is in agreement with Rockenbach et al (2011) who tested TP content in four grape pomace varieties and reported that it was ranged from 33 to $75 \mathrm{mg} \mathrm{GAE} / \mathrm{g}$. While, Butkhup et al (2010) found that TP content in GP was $480 \mathrm{mg}$ $\mathrm{GAE} / \mathrm{g}$. Several factors including environment, degree of maturity, berry size, and variety of grapevines identify phenolic composition in GP (Pourali et al 2014).

Table 4. Total phenolic compounds, total flavonoids and DPPH in GP

\begin{tabular}{|l|c|}
\hline \multicolumn{1}{|c|}{ Item } & Value \\
\hline Total phenolic compounds & $50.35 \pm 0.18^{*}$ \\
Total flavonoids & $22.25 \pm 0.13^{\star *}$ \\
RSA \% using DPPH & $51.92 \pm 0.07^{\star * *}$ \\
\hline
\end{tabular}

* $\mathrm{mg}$ gallic acid equivalent per $\mathrm{g}$ sample as basis $(\mathrm{mg}$ GAE/g)

${ }^{* \star} \mathrm{mg}$ rutin equivalent per $\mathrm{g}$ sample as basis $(\mathrm{mg} \mathrm{RE} / \mathrm{g}$ ) $* * * \%$

Moreover, Table 4, showed that the content of total flavonoids in GP, which expressed as mg rutin equivalent (RE) per gram weight of sample, was
$22.25 \mathrm{mg} \mathrm{RE} / \mathrm{g}$ and the DPPH radical scavenging activity was $51.92 \%$. These results are in same line of Hogan et al (2010). But, according to the study of Xu et al (2016) TF in GP was reached to more than four times of the present result. The difference may be due to the type of extraction method employed.

\subsection{Identification of phenolic compounds}

Classification of polyphenols (phenolic compounds) according to the number of hydroxyl groups and the way of bonding of aromatic ring is based on four main groups. Phenolic acids, flavonoids, lignans and stilbenes (Fabjanowicz et al 2018).

Fourteen phenolic acids in GP were identified using HPLC as presented in Table 5 gallic, protocatchoic, catechol, 4-aminobenzoic, chlorogenic, P$\mathrm{OH}$ - benzoic, caffeic, caffeic, vanillic, p-coumaric, caffeine, ferulic, Iso-ferulic, a coumaric and ellagic As can be seen, gallic acid had the highest value (9.76 mg/100g).

In addition, through HPLC analysis, 11 flavonoid compounds, catechin, naringin, rosmarinic, hesperdin, rutin, quercetrin, hespertin, naringenin, quercetin, kampferol and apigenin were found. Catechin was the most abundant flavonoid compound. These findings are in agreement with Gülcü et al (2018) who reported that catechin and gallic are the most phenolic compounds in GP. Catechins are incorporated into the LDL particles (Suzuki-Sugihara et al 2016), resulting in a reduced oxidization ability of LDL. Moreover, from the same Table, resveratrol as stilbenes content was $14.11 \mathrm{mg} / 100 \mathrm{~g}$. This is a natural polyphenolic compound which shows beneficial health effects such as, anticancer, antimicrobial, antioxidant activity and decrement in levels of TC and TG (Simental-Mendía and Guerrero-Romero 2019).

\subsection{Biological analysis of GP}

As shown in Table 6 there were no significant differences in all tested groups in feed intake. On the other hand, PC group significantly different comparing with other groups in weight gain. This increment was may be due to feeding this group on high fat diet only. These findings seem to be in agreement with Cho et al (2013) who reported that supplementation mice diet with grape pomace extract did not significantly change feed intake among groups.

Data presented in Table 7 demonstrate that the mean values of serum cholesterol, triglycerides, LDL-C and VLDL-C (mg/dl) were significantly 
increased $(P<0.05)$ in the $P C$ in comparison with the NC group. This observation was in agreement with Diab et al (2017). The increment percentage in total cholesterol value in $\mathrm{PC}$ in relative to $\mathrm{NC}$ was about $85.5 \%$. While in case of HDL-C this ratio decreased to be about $33.82 \%$. It could be noticed that supplementation high-fat diet with 5, 10 and $15 \%$ of GP resulted in a significant reduction in total cholesterol (TC) values. Rat groups which received high fat diets with all the previous concentrations of GP had lower mean values of triglycerides (TG), LDL-C and VLDL-C. On the other hand, the same treated rats had higher mean values of HDL-C than that fed on HFD only. The best result for lipid fractions compared with PC was noticed in $15 \%$ GP followed by $10 \%$ GP and the lowest decrement was in $5 \%$ GP.

Table 5. Chromatographic compounds analysis of phenolic acids, flavonoids and stilbenes

\begin{tabular}{|l|l|l|l|l|l|}
\hline Phenolic acids & Amount $\mathbf{( m g / 1 0 0 g )}$ & Flavonoids & $\begin{array}{l}\text { Amount } \\
(\mathbf{m g} / \mathbf{1 0 0})\end{array}$ & Stilbenes & $\begin{array}{l}\text { Amount } \\
\text { (mg/100g) }\end{array}$ \\
\hline Gallic & 9.76 & Catechin & 52.50 & Resveratrol & 14.11 \\
Protocatchoic & 5.27 & Naringin & 10.70 & & \\
Catechol & 2.82 & Rosmarinic & 16.14 & & \\
4-aminobenzoic & 0.41 & Hesperdin & 5.23 & & \\
Chlorogenic & 7.25 & Rutin & 2.23 & & \\
P-OH- benzoic & 5.92 & Quercetrin & 2.00 & \\
Caffeic & 1.35 & Naringenin & 3.1 & \\
Vanillic & 6.72 & Quercetin & 2.56 & & \\
p-Coumaric & 0.10 & Hespertin & 2.08 & & \\
Caffeine & 6.23 & Kampferol & 0.16 & & \\
Ferulic & 0.12 & Apigenin & 0.18 & & \\
Iso-ferulic & 0.76 & & & & \\
a coumaric & 0.03 & & & & \\
Ellagic & 0.13 & & & \\
\hline
\end{tabular}

Table 6. Effect of supplementation with GP on weight gain, feed intake and feed efficiency ratio in tested rats

\begin{tabular}{|c|c|c|c|c|c|}
\hline Rat groups & $\begin{array}{c}\text { Initial weight } \\
\mathbf{( g )}\end{array}$ & $\begin{array}{c}\text { Final weight } \\
\mathbf{( g )}\end{array}$ & $\begin{array}{c}\text { Weight gain } \\
\mathbf{( g )}\end{array}$ & $\begin{array}{c}\text { Feed intake } \\
\mathbf{( g )}\end{array}$ & $\begin{array}{c}\text { Feed } \\
\text { efficiency } \\
\text { ratio }\end{array}$ \\
\hline NC & $185.33^{\mathrm{a}} \pm 1.55$ & $215.51^{\mathrm{b}} \pm 1.64$ & $30.18^{\mathrm{b}} \pm 1.52$ & $825.78^{\mathrm{a}} \pm 1.04$ & $0.037^{\mathrm{b}} \pm 1.11$ \\
PC & $183.00^{\mathrm{a}} \pm 2.51$ & $231.67^{\mathrm{a}} \pm 2.51$ & $48.67^{\mathrm{a}} \pm 2.7$ & $820.63^{\mathrm{a}} \pm 1.63$ & $0.059^{\mathrm{a}} \pm 1.24$ \\
$\mathbf{5 \%}$ GP & $184.67^{\mathrm{a}} \pm 1.51$ & $217.11^{\mathrm{b}} \pm 1.52$ & $32.44^{\mathrm{b}} \pm 2.51$ & $826.68^{\mathrm{a}} \pm 1.08$ & $0.039^{\mathrm{b}} \pm 1.51$ \\
$\mathbf{1 0 \%}$ GP & $188.54^{\mathrm{a}} \pm 2.51$ & $219.24^{\mathrm{b}} \pm 1.57$ & $30.70^{\mathrm{b}} \pm 2.64$ & $819.25^{\mathrm{a}} \pm 1.05$ & $0.037^{\mathrm{b}} \pm 1.84$ \\
$\mathbf{1 5 \%}$ GP & $190.00^{\mathrm{a}} \pm 1.55$ & $221.33^{\mathrm{b}} \pm 1.15$ & $31.33^{\mathrm{b}} \pm 1.70$ & $824.32^{\mathrm{a}} \pm 1.02$ & $0.038^{\mathrm{b}} \pm 1.37$ \\
\hline
\end{tabular}

Each value represents the mean \pm standard deviation (SD) $\quad \mathrm{NC}=$ Negative control $\quad \mathrm{PC}=$ Positive control $\mathrm{GP}=$ Grape pomace $\quad 5 \% \mathrm{GP}=\mathrm{HFD}+5 \% \mathrm{GP} \quad 10 \% \mathrm{GP}=\mathrm{HFD}+10 \% \mathrm{GP} \quad 15 \% \mathrm{GP}=\mathrm{HFD}+15 \% \mathrm{GP}$ The mean values within the same column with different superscript alphabets indicate significant differences $(P<0.05)$ Feed efficiency ratio was calculated as gain of weight $(\mathrm{g}) /$ total feed intake $(\mathrm{g})$ 
Table 7. Effect of supplementation with GP on lipid profile of the tested rat groups serum

\begin{tabular}{|c|c|c|c|c|c|}
\hline Rat groups & $\begin{array}{c}\text { Total cholesterol } \\
(\mathrm{mg} / \mathrm{dl})\end{array}$ & $\begin{array}{l}\text { Triglycerides } \\
\text { (mg/dl) }\end{array}$ & $\begin{array}{l}\text { HDL-C } \\
\text { (mg/dl) }\end{array}$ & $\begin{array}{l}\text { LDL-C } \\
(\mathrm{mg} / \mathrm{dl})\end{array}$ & $\begin{array}{l}\text { VLDL-C } \\
(\mathrm{mg} / \mathrm{dl})\end{array}$ \\
\hline NC & $89.66^{e} \pm 5.03$ & $103.00^{\mathrm{d}} \pm 4.9$ & $45.33^{a} \pm 1.5$ & $23.73^{\mathrm{e}} \pm 4.2$ & $20.60^{\mathrm{d}} \pm 0.9$ \\
\hline PC & $166.33^{a} \pm 1.5$ & $178.00^{\mathrm{a}} \pm 4.0$ & $30.00^{\mathrm{d}} \pm 2.0$ & $100.73^{a} \pm 2.2$ & $35.60^{\mathrm{a}} \pm 0.8$ \\
\hline $5 \% \mathrm{GP}$ & $131.33^{b} \pm 3.5$ & $140.00^{\mathrm{b}} \pm 3.0$ & $38.00^{\mathrm{c}} \pm 2.0$ & $65.33^{\mathrm{b}} \pm 4.3$ & $28.00^{\mathrm{b}} \pm 0.6$ \\
\hline $10 \%$ GP & $121.33^{c} \pm 3.5$ & $125.66^{c} \pm 2.5$ & $41.00^{\mathrm{b}} \pm 1.0$ & $55.20^{c} \pm 3.3$ & $25.13^{\mathrm{c}} \pm 0.5$ \\
\hline $15 \%$ GP & $98.33^{\mathrm{d}} \pm 2.5$ & $108.66^{\mathrm{d}} \pm 2.5$ & $41.69^{\mathrm{b}} \pm 0.6$ & $34.90^{\mathrm{d}} \pm 1.9$ & $21.73^{\mathrm{d}} \pm 0.5$ \\
\hline \multicolumn{6}{|c|}{ Each value represents the mean \pm standard deviation $(S D)$} \\
\hline \multicolumn{3}{|c|}{$\mathrm{GP}=$ Grape pomace } & $P=H F D+10 \%$ & \multicolumn{2}{|c|}{$15 \% G P=H F D+15 \% G P$} \\
\hline
\end{tabular}

These findings are in good agreement with a study by Smith et al (2017) who investigated the effect of rats' diets containing different amounts of GP $(6.9 \%-20.7 \%)$ on blood lipid profile and found that as GP increased, the blood triglycerides and very low-density lipoproteins (vLDL-C) decreased, while the high-density lipoprotein (HDL-C) increased. On the other hand, the increment in low-density lipoprotein (LDL-C) and total cholesterol remained constant.

In the same direction, El Ayed et al (2017) mentioned that grape seed and skin extracts successfully backed triglycerides, cholesterol, and LDL cholesterol to near the control level, while the HDL-C level was maintained higher than the control level in rats that fed on a high fat diet with grape seed and skin extracts.

Martin-Carron et al (2000) stated that the assayed polyphenols rich grape product was successful in reducing total cholesterol and LDL-C in serum by improving HDL: LDL ratio and the atherogenic index in hypercholesterolemic rats.

The improvement in lipid profile of the studied rats according to the current research as a result of supplementing the HFD diet with GP may be due to the dietary fiber content (DF) in GP. Since, soluble dietary fiber can decrease blood cholesterol levels and glycemic responses. Whereas, in the large intestine, DF is fermented, fiber strengthens the colonic environment. In addition, it slows and interferes with cholesterol and bile acid absorption. Insoluble dietary fiber has vital effects by increasing fecal bulk, having benefits in intestinal motility, lowering gastric emptying, and promoting satiety (García-Lomillo and González-SanJosé 2017).
As seen in Table 8 it could be noticed that rats' serum of $P C$ had a significant higher mean values of AST, ALT, urea, uric acid and creatinine than that of NC. When GP levels (5, 10 and 15\%), were added to the high fat diet of rats, the levels of these parameters were decreased in comparison to the PC group. Furthermore, by increment of GP levels in rats' diets, the decrement in these parameters was observed.

Thus, the best result for these studied parameters (AST, ALT, urea, uric acid and creatinine) were noticed in the group of rats fed on the high fat diet containing $15 \%$ GP. It could be detected that there was a non-significant changes in the levels of AST, ALT, uric acid and creatinine compared with (NC).

In the present study, the HFD stimulate an increase in AST and ALT serum levels, which is in agreement with Lacerda et al (2018). The raise in urea, uric acid and creatinine levels in $P C$ is in the line with Gara et al (2017) and Diab et al (2017) who found that serum uric acid, urea, and creatinine were significantly increased in HFD groups for male and female rats.

The present study revealed a significant reduction in AST and ALT values in the studied rats when GP was added to HFD. This observation is agreed with Al-Attar (2015) who found that the grape seed oil is able to reduce the activity of AST and ALT in rats as well as, decrease urea, uric acid and creatinine levels in groups fed on high fat diet and GP.

Moreover, Amin et al (2018) studied the Renoprotective effect of grape seed extract in diabetic rats and found a significant improvement in liver and kidney functions'.

The improvement in both liver and kidney vital functions is attributed to the presence of phenolic compounds (Spacil et al 2008). 
Table 8. The levels of AST, ALT, urea, uric acid and creatinine in the tested rat groups serum

\begin{tabular}{|c|c|c|c|c|c|}
\hline Rat groups & $\begin{array}{c}\text { AST } \\
\mathbf{U} / \mathbf{L}\end{array}$ & $\begin{array}{c}\mathbf{A L T} \\
\mathbf{U} / \mathbf{L}\end{array}$ & $\begin{array}{c}\text { Urea } \\
\mathbf{m g} / \mathbf{d l}\end{array}$ & $\begin{array}{c}\text { Uric acid } \\
\mathbf{m g} / \mathbf{d l}\end{array}$ & $\begin{array}{c}\text { Creatinine } \\
\mathbf{m g} / \mathbf{d l}\end{array}$ \\
\hline NC & $40.00^{\mathrm{d}} \pm 2.08$ & $28.83^{\mathrm{c}} \pm 1.58$ & $36.32^{\mathrm{d}} \pm 1.66$ & $2.80^{\mathrm{c}} \pm 0.10$ & $0.73^{\mathrm{d}} \pm 0.06$ \\
PC & $63.66^{\mathrm{a}} \pm 4.33$ & $43.33^{\mathrm{a}} \pm 1.70$ & $71.00^{\mathrm{a}} \pm 3.05$ & $6.56^{\mathrm{a}} \pm 0.44$ & $2.72^{\mathrm{a}} \pm 0.16$ \\
$5 \%$ GP & $57.00^{\mathrm{ab}} \pm 0.57$ & $42.22^{\mathrm{a}} \pm 0.17$ & $60.66^{\mathrm{b}} \pm 2.84$ & $6.10^{\mathrm{a}} \pm 0.06$ & $2.05^{\mathrm{b}} \pm 0.03$ \\
$10 \%$ GP & $52.00^{\mathrm{bc}} \pm 0.57$ & $36.62^{\mathrm{b}} \pm 1.70$ & $53.00^{\mathrm{c}} \pm 0.57$ & $5.19^{\mathrm{b}} \pm 0.03$ & $1.50^{\mathrm{c}} \pm 0.09$ \\
$15 \%$ GP & $45.33^{\mathrm{cd}} \pm 2.72$ & $30.41^{\mathrm{c}} \pm 0.61$ & $46.00^{\mathrm{c}} \pm 2.08$ & $3.20^{\mathrm{c}} \pm 0.03$ & $0.88^{\mathrm{d}} \pm 0.06$ \\
\hline
\end{tabular}

Each value represents the mean \pm standard deviation (SD) $\quad \mathrm{NC}=$ Negative control $\quad \mathrm{PC}=\mathrm{Positive}$ control $\mathrm{GP}=$ Grape pomace $\quad 5 \% \mathrm{GP}=\mathrm{HFD}+5 \% \mathrm{GP} \quad 10 \% \mathrm{GP}=\mathrm{HFD}+10 \% \mathrm{GP} \quad 15 \% \mathrm{GP}=\mathrm{HFD}+15 \% \mathrm{GP}$ The mean values with different superscript alphabets indicate significant differences $(P<0.05)$

\section{Conclusion}

Grape pomace is rich in mineral and dietary fibers. It is, also, a good source of total phenolic and total flavonoids which provide its antioxidant activity potential. Supplementation high fat diet with GP exhibited beneficial effects on blood lipid profile. As well as, on liver and kidney functions.GP could be as a source of healthy and technological compounds that should be applied in animal feed, pharmaceutical, cosmetic or food industry to improve stability and nutritional characteristics in the future.

\section{References}

Al-Attar, A (2015) Effect of grape seed oil on diazinon-induced physiological and histopathological alterations in rats. Saudi J of Bio Sci 22, 284-292.

Allain, C; Poon, L; Chan, C (1974) Enzymatic determination of total serum cholesterol. Clin Chem 20, 470-475.

Amin, K; Ahmed, R; Hozayen, S; Alshehri, F; Al-Muzafar, H (2018) Renoprotective effect of grape seed extract in diabetic nephropathy by attenuating hyperglycemia-facilitated oxidative stress. Int J Clin Exp Med 11, 12285-12293.

Anđelković, M; Radovanović, B; Anđelković, A; Radovanović, V; Zarubica, A; Stojković, N; Nikolić, $\mathrm{V}$ (2015) The determination of bioactive ingredients of grape pomace (vranac variety) for potential use in food and pharmaceutical industries. Advanced Technologies 4, 32-36.

AOAC (2006) Official Methods of Analysis, $18^{\text {th }}$ Edition, Association of Official Agricultural Chemists, Washington DC, USA.
Arnous, A; Makris, D; Kefalas, P (2001) Effect of principal polyphenol components in relation to antioxidant characteristics of aged red wines. J Agric Food Chem 49, 5736-5742.

Bampi, M; Bicudo, M; Fontoura Ribani, R (2010) Chemical composition of fruit concentrated extract and flour from Japanese grape. Ciência Rural 40, 2361-2367.

Bergmeyer, U; Harder, M (1986) A colorimetric method of determination of serum glutamic oxaloacetic and pyruvic transaminase. Clin Biochem 24, 28-34.

Bonsens, K; Taussky, D (1984) Determination of serum creatinine. J Chem Inv 27, 648-660.

Bouveresse, R; Pinto, C; Schmidtke, M; Locquet, N; Rutledge, N (2011) Identification of significant factors by an extension of ANOVA-PCA based on multi-block analysis. Chemo Metrics and Intelligent Laboratory Systems 106, 173-182.

Brand-Williams, W; Cuvelier, M; Berset. C (1995) Use of a free radical method to evaluate antioxidant activity. LWT-Food Sci and Technol 28, 25.

Butkhup, L; Chowtivannakul, S; Gaensakoo, R; Prathepha, P; Samappito, S (2010) Study of the Phenolic Composition of Shiraz Red Grape Cultivar ( Vitis vinifera L.) Cultivated in North-eastern Thailand and its Antioxidant and antimicrobial Activity $S$ Afr $J$ Enol Vitic 31, 89-98.

Cetin, E; Altinöz, D; Tarçan, E; Baydar, N (2011) Chemical composition of grape canes. Industrial Crops and Products 34, 994-998. 
Cho, S.; Park, Y; Jung, U; Park, H; Kim, S; Kim, H; Choi, M (2013) Combined ethanol extract of grape pomace and omija fruit ameliorates adipogenesis, hepatic steatosis, and inflammation in diet-induced obese mice. Evidence-based complementary and Alternative Medicine 1, 1-11.

Deng, Q; Penner, M; Zhao, Y (2011) Chemical composition of dietary fiber and polyphenols of five different varieties of wine grape pomace skins. Food Research International 44, 2712-2720.

Diab, A; Asala, A; Hendawy, A; Moursi, S; Shaban, M (2017) Effect of caloric restriction on renal function in a rat model of high fat diet induced obesity. Med J Cairo Univ, Cairo, Egypt 85, 3071-3086.

El-Ayed, M; Kadri, S.; Smine, S; Elkahoui, S; Limam, F; Aouani, Z (2017) Protective effects of grape seed and skin extract against high-fat-diet-induced lipotoxicity in rat lung. Lipids in Health and Disease 16, 174.

Fabjanowicz, M; Płotka-Wysyłka, J; Namieśnik, J (2018) Detection, identification and determination of resveratrol in wine. Problems and challenges. Trends in Analytical Chemistry 103, 21-33.

Fernandes, L; Casal, S; Cruz, R; Pereira, J; Ramalhosa, E (2013) Seed oils of ten traditional Portuguese grape varieties with interesting chemical and antioxidant properties. Food Research International 50, 161-166.

Fontana, A; Antoniolli, A; Bottini, R (2013) Grape pomace as a sustainable source of bioactive compounds: extraction, characterization, and biotechnological applications of phenolics. $J$ of Agric and Food Chem 61, 8987-9003.

Food and Agriculture Organization of the United Nations (2012) FAOSTAT database. FAOSTAT (Available from: http://faostat3.fao.orgN).

Fossati, P; Prencipe, L (1982) The determination of triglycerides using enzymatic methods. Clin Chem 28, 2077-2081.

Fossati, P; Prencipe, L; Berti, G (1980) Use of 3, 5Dichloro- 2-hydroxybenzenesulfonic Acid/4-Ami nophenazone Chromogenic System in Direct Enzymic Assay of Uric Acid in Serum and Urine. Clin Chem 26, 227-231.

Friedewald, W; Levy, R; Fredrickson, D (1972) Estimation of the concentration of low-density lipoprotein cholesterol in plasma, without use the preparative ultracentrifuge. Clin Chem 18, 499-502.
Gara, A; Kolsi, R; Chaaben, R; Hammami, N; Kammoun, M; Patti, F; El-Feki, A; Fki, L; Belghith, H; Belghith, $\mathrm{K}$ (2017) Inhibition of key digestive enzymes related to hyperlipidemia and protection of liver-kidney functions by cystoseira crinita sulphated polysaccharide in high-fat diet-fed rats. Biomed Pharmacotherapy 85, 517-526.

García-Lomillo, J; González-SanJosé, M (2017) Applications of Wine Pomace in the Food Industry: Approaches and Functions. Comprehensive Rev. in Food Sci and Food Safety 16, 1-22.

Guemour, D; Bannelier, C; Dellal, A; Gidenne, T (2010) Nutritive value of sun-dried grape pomace, incorporated at a low level in complete feed for the rabbit bred under magrebian conditions. World Rabbit Sci 18, 17-25.

Gülcü, M; Uslu, N; Özcan, M; Gökmen, F; Özcan, M; Banjanin, T; Gezgin, S; Dursun, N; Geçgel, Ü; Ceylan, D; Lemiasheuski, V (2018) The investigation of bioactive compounds of wine, grape juice and boiled grape juice wastes. J of Food Processing and Preservation 43, 1-14.

Hertog, M (1993) Dietary antioxidant flavonoids and risk of coronary heart disease: The Zutphen Elderly Study Lancet 342, 1007-1011.

Hogan, S; Zhang, L; Li, J; Sun, S; Canning, C; Zhou, K (2010) Antioxidant rich grape pomace extract suppresses postprandial hyperglycemia in diabetic mice by specifically inhibiting alpha-glucosidase. Nutrition \& Metabolism 7, 1-9.

International Organization for Standardization (ISO) (2011) Animal and vegetable fats and oils. Gas chromatography of fatty acids methyl esters and preparation of methyl esters of fatty acids, pp 12966-22011.

Joyeux, M; Lobstein, A; Anton, R; Mortier, F (1995) Comparative anti-lipoperoxidant, anti-necrotic and scavenging potencies of terpenes and biflavones from Ginko and some flavonoids. Planta Med 61, 126-129.

Lacerda, D; Almeida, M; Teixeira, C; Jesus, A; Júnior, É; Patrícia, B; Henriques, R; Dani, C; Funchal, C (2018) Biochemical and Physiological Parameters in Rats Fed with High-Fat Diet: The Protective Effect of Chronic Treatment with Purple Grape Juice (Bordo Variety). Beverages 4, 1-13.

Lee, S; Choi, S; Seo, J (2009) Grape skin improves antioxidant capacity in rats fed a high fat diet. Nutr Res Pract 3, 279-285. 
Llobera, A; Cañellas, J (2007) Dietary fibre content and antioxidant activity of Manto Negro red grape (Vitis vinifera): pomace and stem. Food Chem 101, 659- 666.

Lopes-Virella, F; Stone, S; Ellis, S; Collwellm, J (1977) Cholesterol determination in high density lipoproteins separated by three different methods. Clin Chem 23, 882-893.

Manach, C; Williamson, C; Morand, A; Remesy, S (2005) Bioavailability and bio efficacy of polyphenols in humans. I. Review of 97 bioavailability Studies. Am J Clin Nutr 81, 230S-242S.

Martin-Carron, N; Saura-Calixto, F; Goni, I (2000) Effect of dietary fiber- and polyphenol-rich grape products on lipidaemia and nutritional parameters in rats. J Sci Food Agric 80, 1183-1188.

Mildner-Szkudlarz, S; Bajerska, J (2013) Protective effect of grape by product fortified breads against cholesterol/cholic acid diet-induced hypercholesterolaemia in rats. $J$ of the Sci of Food and Agric 93, 3271-3278.

Ministry of Agriculture, Agricultural Development System Project, ADS, 2006.

Patton, C; Crouch, S (1977) Spectrophotometric and kinetics investigation of the Berthelot reaction for the determination of ammonia. Anal Chem 49, 464-469.

Pourali, A; Afrouziyeh, M; Moghaddaszadeh-ahrabi, $S$ (2014) Extraction of phenolic compounds and quantification of the total phenol of grape pomace. European J Exp Biology 4, 174-176.

Reeves, P; Nielsen, F; Fahey, G (1993) AIN-93 purified diets for laboratory rodents: final report of the American Institute of Nutrition ad hoc writing committee on the reformulation of the AIN-76A rodent diet. J Nutr 123, 1939-1951.

Rockenbach, I; Rodrigues, E; Gonzaga, LV; Genovese, MI; Gonçalves, AE; Fett, R (2011) Phenolic compounds content and antioxidant activity in pomace from selected red grapes (Vitis vinifera $L$. and Vitis labrusca L.) widely produced in Brazil. Food Chemistry 127, 174-179.

Sagdic, O; Ozturk, I; Ozkan, G; Yetim, H; Ekici, L Yilmaz, M (2011) RP-HPLC-DAD analysis of phenolic compounds in pomace extracts from five grape cultivars: Evaluation of their antioxidant, antiradica and antifungal activities in orange and apple juices. Food Chemistry 126, 1749-1758.
Simental-Mendía, L; Guerrero-Romero, F (2019) Effect of resveratrol supplementation on lipid profile in subjects with dyslipidemia: A randomized doubleblind, placebo-controlled trial. Nutrition 58, 7-10.

Smith, I; Yu, J; Hurley, S; Hanner, T (2017) Impact of diet containing grape pomace on growth performance and blood lipid profile of young rats. $J$ Med Food 20, 550-556.

Sousa, C; Uchôa-thomaz, M; Carioca, O; Morais, M; Lima, D; Martins, G; Alexandrino, D; Ferreira, A; Rodrigues, L; Rodrigues, P; Silva, N; Rodrigues, L (2014) Chemical composition and bioactive compounds of grape pomace (Vitis vinifera L.), Benitaka variety, grown in the semiarid region of Northeast Brazil. Food Sci Technol Campinas 34, 135-142.

Spacil, Z; Novakova, L; Solich, P (2008) Analysis of phenolic compounds by high performance liquid chromatography and ultra-performance liquid chromatography. Talanta 76, 189-199.

Suzuki-Sugihara, N; Kishimoto, Y; Saita, E; Taguchi, C; Kobayashi, M; Ichitani, M; Ukawa, Y; Sagesaka, YM; Suzuki, E; Kondo, K (2016) Green tea catechins prevent low-density lipoprotein oxidation via their accumulation in low-density lipoprotein particles in humans. Nutr Res 36, 16-23.

Tangolar, SY; Tangolar, S; Torun, A (2009) Evaluation of fatty acid profiles and mineral content of grape seed oil of some grape genotypes. International $J$ of Food Sci and Nutri 60, 32-39.

Wang, Q; Zuberi, R; Zhang, H; Macgowan, J; Qin, J; Yea, X; Son, L; Wu, Q; Lian, K; Cefalu, T (2007) Effects of dietary fibers on weight gain, carbohydrate metabolism, and gastric ghrelin gene expression in mice fed a high-fat diet. Metabolism Clinical and Experimental 56, 1635-1642.

Xu, Y; Burton, S; Kim, C; Sismour, E (2016) Phenolic compounds, antioxidant, and antibacterial properties of pomace extract from four Virginiagrown grape varieties. Food Sci \& Nutri 4, 125-133.

Yilmaz, Y; Toledo, RT (2006) Oxygen radical absorbance capacities of grape/wine industry by products and effect of solvent type on extraction of grape seed polyphenols. J of Food Composition and Analysis 19, 41-48.

Ziarati, P; Moshiri, I; Sadeghi, P; Mohammadi, S (2017) Grape pomace flour (Vitis spp.) from Shiraz in south of Iran by high trace mineral elements as food supplements. SF Drug Deliv Res J 1, 1-9. 
مجلة اتحاد الجامعات العربية للعلوم الزراعية، جامعة عين شمس، القاهرة، مصر

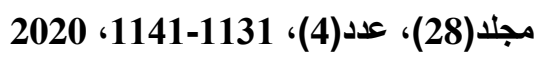

Website: http://ajs.journals.ekb.eg

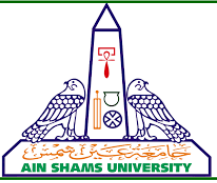

تأثير مخلف تصنيع العنب علي بعض الإختبارات البيولوجية لفئران التجارب

$[80]$

\author{
مها عبدالله محمود - هاله على ثابت" - الثحات جمعه الارينى \\ قسم الأغذية الخاصة والتغذية - معهد بحوث تكنولوجيا الأغذية - مركز البحوث الزراعية - الجيزة - مصر
}

*Corresponding author: drhala.thabet@gmail.com

Received 9 July, 2020

Accepted 2 October, 2020

22 ملليجرام مكافئ روتين لكل 100 جرام من العينة.

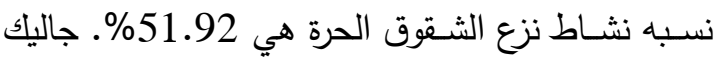

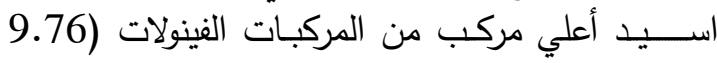

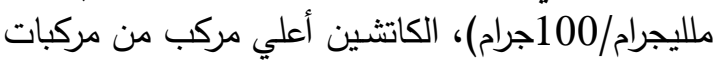

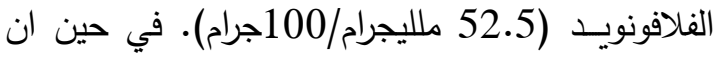

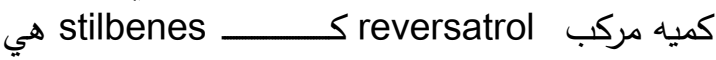

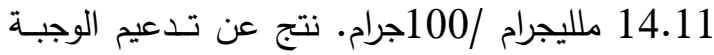

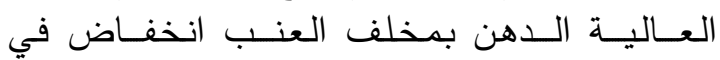

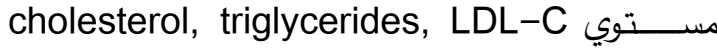
and vLDL-C المغذاه علي الوجبه المدعمه بمخلف العنب أعلي مقارنه

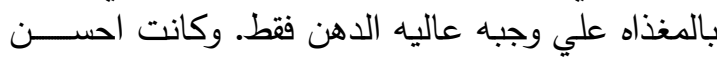

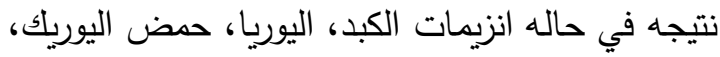
الكرياتتين في الفئران المغذاه علي وجبهاته عاليه الئه الدهن

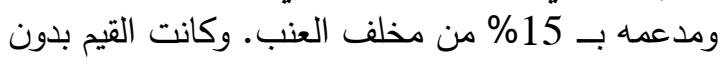

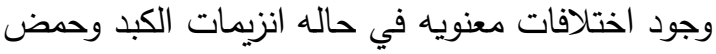
اليوريك والكرياتتين مقارنة بالمجموعه الضابطات التهات السالبه.

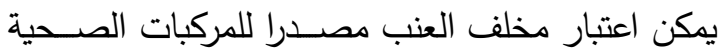
والتكنولوجيه. كذلك يمكن اسـتخدامه في تغذيه الحيوان,

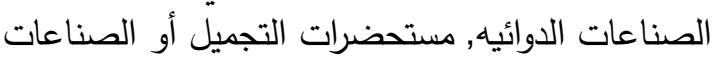
الغذائيه لتحسين خواص الثبات والخصائص الغذائية.

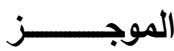

أجريت هذه الدراســـــة بغرض تقليل تأثيرالمخلفات

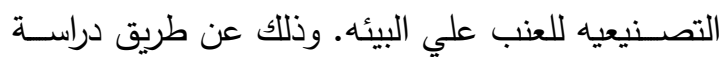

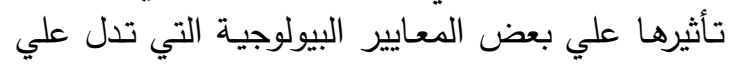

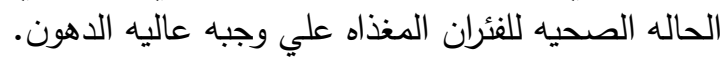

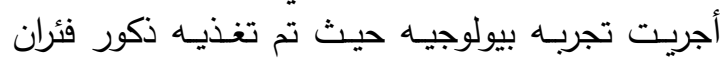
الألبينو (وزن 185 ـ 5 جرام)علي وجبه عالية الدهون تئه

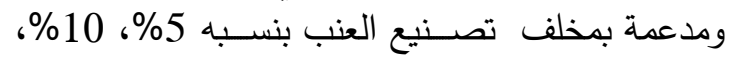

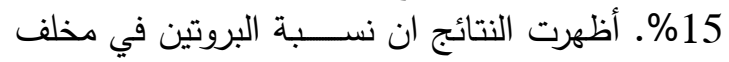

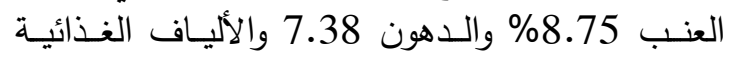

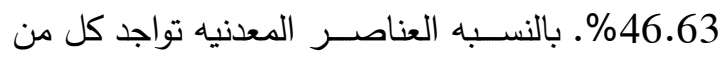

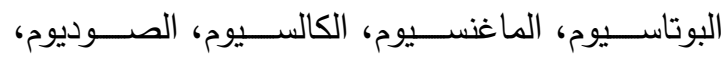

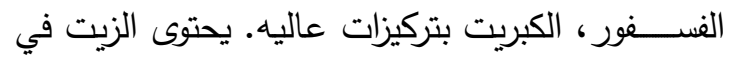

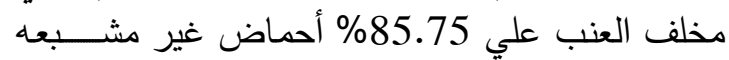

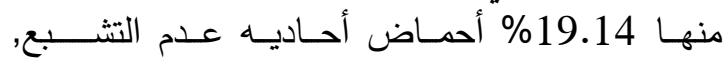

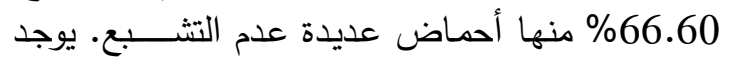

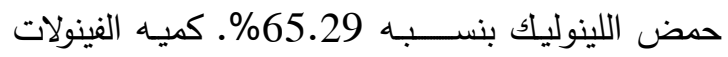
الكليه (معبرا عنها بملليجرام مكافئ حمض الجاليك ليك لكل

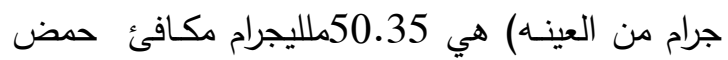
الجاليك لكل جرام. كميه الفلافونويدات الكليه (معبرا

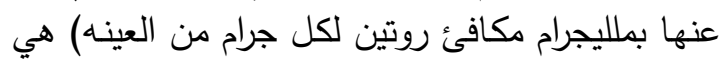

